\title{
Two New Tryptamine Derivatives, Leptoclinidamide and (-)-Leptoclinidamine B, from an Indonesian Ascidian Leptoclinides dubius
}

\author{
Hiroyuki Yamazaki ${ }^{1}$, Defny S. Wewengkang ${ }^{1,2}$, Teruaki Nishikawa ${ }^{3}$, Henki Rotinsulu ${ }^{1}$, \\ Remy E. P. Mangindaan ${ }^{2}$ and Michio Namikoshi ${ }^{1, *}$
}

1 Department of Natural Product Chemistry, Tohoku Pharmaceutical University, Komatsushima, Aoba-ku, Sendai 981-8558, Japan; E-Mails: yamazaki@tohoku-pharm.ac.jp (H.Y.); wdefny@yahoo.com (D.S.W.); rhenki@yahoo.com (H.R.)

2 Faculty of Fisheries and Marine Science, Sam Ratulangi University, Kampus Bahu, Manado 95115, Indonesia; E-Mail: remysang@yahoo.com

3 Laboratory of Taxonomy, Department of Biology, Faculty of Science, Toho University, Miyama, Funabashi 274-8510, Japan; E-Mail: nishikawa@bio.sci.toho-u.ac.jp

* Author to whom correspondence should be addressed; E-Mail: mnami@tohoku-pharm.ac.jp; Tel./Fax: +81-22-727-0219.

Received: 27 December 2011; in revised form: 23 January 2012 / Accepted: 7 February 2012 / Published: 10 February 2012

\begin{abstract}
Two new tryptamine-derived alkaloids, named as leptoclinidamide (1) and (-)-leptoclinidamine B (2), were isolated from an Indonesian ascidian Leptoclinides dubius together with $C^{2}$ - $\alpha$-D-mannosylpyranosyl-L-tryptophan (3). The structure of 1 was assigned on the basis of spectroscopic data for 1 and its $N$-acetyl derivative (4). Compound 1 was an amide of tryptamine with two $\beta$-alanine units. Although the planar structure of $\mathbf{2}$ is identical to that of the known compound (+)-leptoclinidamine B (5), compound $\mathbf{2}$ was determined to be the enantiomer of $\mathbf{5}$ based on amino acid analysis using HPLC methods. Compounds $\mathbf{1}$ to $\mathbf{4}$ were evaluated for cytotoxicity against two human cancer cell lines, HCT-15 (colon) and Jurkat (T-cell lymphoma) cells, but none of the compounds showed activity.
\end{abstract}

Keywords: leptoclinidamide; leptoclinidamine; tryptamine; alkaloid; Indonesian ascidian; Leptoclinides dubius 


\section{Introduction}

Ascidians are a rich source of biologically-active nitrogenous substances with high chemical diversity [1,2]. More than $80 \%$ of new compounds from ascidians contained nitrogen, and about $70 \%$ of nitrogenous compounds are alkaloids [3].

In the course of our studies on the bioactive components from marine invertebrates, we found that the EtOH extract of an Indonesian ascidian Leptoclinides dubius inhibited the growth of Escherichia coli. Chemical study on the EtOH extract led to the isolation of two tryptamine-derived alkaloids, a $C$-glycosylated tryptophan and an antibacterial compound. Two alkaloids were revealed to be new compounds and named as leptoclinidamide (1) and (-)-leptoclinidamine B (2, Figure 1), and a tryptophan derivative was assigned as $C^{2}$ - $\alpha$-D-mannosylpyranosyl-L-tryptophan (3) [4-8]. The major bioactive constituent could not be identified because the amount obtained from the ascidian was not enough to measure 2D NMR spectra.

Figure 1. Structures of leptoclinidamide (1), (-)-leptoclinidamine B (2), and $C^{2}$-a-D-mannosylpyranosyl-L-tryptophan (3).

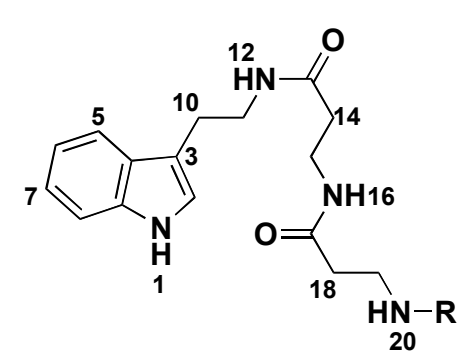

$\mathbf{R}=\mathbf{H}:$ Leptoclinidamide (1) $\mathrm{R}=\mathrm{Ac}: \mathrm{N}$-Acetyl leptoclinidamide (4)

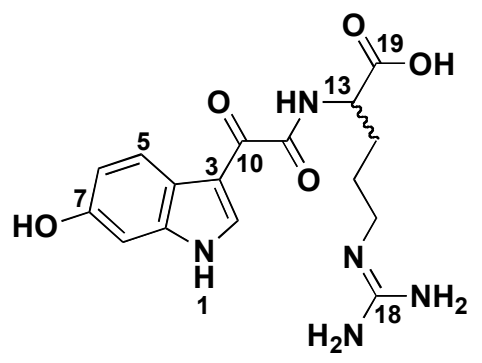

(-)-Leptoclinidamine $B(13 R, 2) \quad C^{2}-\alpha$-D-mannosylpyranosyl-L-tryptophan (3)
HO

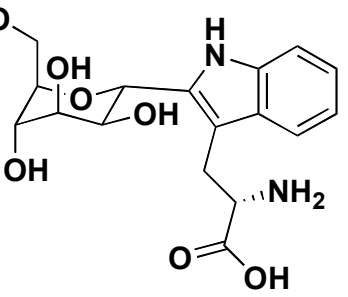

We report herein the isolation and structures of two new tryptamine-derived alkaloids leptoclinidamide (1) and (-)-leptoclinidamine B (2), which had unique amide moiety with two $\beta$-alanine units and D-arginine moiety, respectively.

\section{Results and Discussion}

The EtOH extract of an Indonesian ascidian L. dubius showed antimicrobial activity in the screening bioassay against Escherichia coli and was separated into nine fractions (fraction 1-fraction 9) by octadecylsilyl (ODS) column chromatography. Leptoclinidamide (1) was isolated from fraction 6 (50\% MeOH eluate) by HPLC (ODS) and compounds 2 and 3 were obtained from fraction 3 (30\% $\mathrm{MeOH}$ eluate) and fraction 2 (water eluate), respectively. The antibacterial activity against $E$. coli was detected in fraction $5(50 \% \mathrm{MeOH}$ eluate, $10 \mathrm{~mm}$ inhibition zone at $250 \mu \mathrm{g} / \mathrm{disk})$, and HPLC separation of fraction 5 gave an antibacterial compound as a single HPLC peak.

Unfortunately, the antibacterial component did not give an informative ${ }^{1} \mathrm{H}$ NMR spectrum because of the small amounts obtained, and, therefore, 2D NMR experiments could not be recorded. The structure of compound 3 was assigned on the basis of its spectral data and comparison with that of the reported values for $C^{2}$ - $\alpha$-D-mannosylpyranosyl-L-tryptophan [6,7]. Compound 3 was first identified as 
a novel post-translationally modified tryptophan in human RNases [4] and isolated thereafter from the ascidian L. dubius in 2000 [8], but the role of compound $\mathbf{3}$ have not yet been elucidated.

Leptoclinidamide (1) was obtained as a TFA salt. The FAB-MS spectrum of $\mathbf{1}$ showed a peak at $\mathrm{m} / \mathrm{z}$ 303.1821, and $16{ }^{13} \mathrm{C}$ signals were detected in the ${ }^{13} \mathrm{C}$ NMR spectrum (DMSO- $d_{6}$ ). However, the ${ }^{1} \mathrm{H}$ signals due to amine moiety were observed as broad peak in the NMR spectrum of 1 . Therefore, the molecular weight and formula of $\mathbf{1}$ were confirmed by the spectroscopic data for an $N$-acetyl derivative (4) of 1. Compound 4 gave an $[\mathrm{M}+\mathrm{H}]^{+}$ion at $m / z 345.1930$ in the HRFAB-MS, and the molecular formula of 4 was determined as $\mathrm{C}_{18} \mathrm{H}_{25} \mathrm{~N}_{4} \mathrm{O}_{3}$. Accordingly, the molecular formula of $\mathbf{1}$, which revealed an $[\mathrm{M}+\mathrm{H}]^{+}$ion at $m / z 303.1821$ in the HRFAB-MS, were deduced as $\mathrm{C}_{16} \mathrm{H}_{22} \mathrm{~N}_{4} \mathrm{O}_{2}$ (8 degrees of unsaturation).

The IR spectrum of 1 showed absorption bands at 1681 and $1584 \mathrm{~cm}^{-1}$, which were ascribable to two amide carbonyl groups. The ${ }^{13} \mathrm{C}$ signals of 1 were classified into six methylene, four $s p^{2}$ methine, one nitrogenated $s p^{2}$ methine, two $s p^{2}$ quaternary, one nitrogenated $s p^{2}$ quaternary and two amide carbonyl carbons by the analysis of ${ }^{13} \mathrm{C}$ NMR, DEPT and HMQC spectra of 1 . The ${ }^{1} \mathrm{H}$ NMR spectrum (DMSO- $d_{6}$ ) of 1 displayed 22 signals including $N$-H protons due to a primary amine $\left(\delta_{\mathrm{H}} 7.66,2 \mathrm{H}\right)$, two amides $\left(\delta_{\mathrm{H}} 7.93\right.$ and 8.07), and an indole ring $\left(\delta_{\mathrm{H}} 10.8\right)$. Table 1 shows ${ }^{1} \mathrm{H}$ and ${ }^{13} \mathrm{C} \mathrm{NMR}$ data for 1 assigned by the analysis of ${ }^{1} \mathrm{H}-{ }^{1} \mathrm{H}$ COSY, HMQC and HMBC spectra. The ${ }^{1} \mathrm{H}-{ }^{1} \mathrm{H}$ COSY spectrum of 1 revealed the partial structures I through $\mathrm{V}$ (Figure 2). The presence of an indole ring was suggested by the ${ }^{1} \mathrm{H}$ NMR signals at $\delta 7.09(\mathrm{H}-2), 7.48(\mathrm{H}-5), 6.93$ (H-6), 7.02 (H-7), $7.29(\mathrm{H}-8)$, and 10.8 $(1-\mathrm{NH})$ and $\mathrm{HMBC}$ correlations from these signals to the expected ${ }^{13} \mathrm{C}$ NMR signals. HMBC correlations from $\mathrm{H}_{2}-10\left(\delta_{\mathrm{H}} 2.77\right)$ to $\mathrm{C}-2\left(\delta_{\mathrm{C}} 122.5\right), \mathrm{C}-3\left(\delta_{\mathrm{C}} 111.8\right)$, and C-4 $\left(\delta_{\mathrm{C}} 127.2\right)$ and from $\mathrm{H}_{2}-11\left(\delta_{\mathrm{H}} 3.29\right)$ to $\mathrm{C}-3$ revealed a tryptamine unit in the molecule of 1 . The ${ }^{1} \mathrm{H}$ NMR signals at $\delta 3.29$ $\left(\mathrm{H}_{2}-11\right)$ showed an $\mathrm{HMBC}$ correlation to one of two amide carbonyl carbons at $\delta_{\mathrm{C}} 170.0(\mathrm{C}-13)$. The other amide linkage was determined by HMBC correlations to $\mathrm{C}-17\left(\delta_{\mathrm{C}} 169.2\right)$ from $16-\mathrm{NH}\left(\delta_{\mathrm{H}} 8.07\right)$, $\mathrm{H}_{2}-18\left(\delta_{\mathrm{H}} 2.38\right)$, and $\mathrm{H}_{2}-19\left(\delta_{\mathrm{H}} 2.93\right)$. These data suggested the structure of 1 as shown in Figure 1. The structure of 1 was further confirmed by the analysis of the $N$-acetyl derivative (4). The ${ }^{1} \mathrm{H}$ NMR spectrum of 4 showed new signals corresponding to a methyl proton signal at $\delta 1.75$ and a new amide proton signal at $\delta_{\mathrm{H}} 7.78$ and a corresponding loss of two primary amine proton signals detected in the ${ }^{1} \mathrm{H}$ NMR spectrum of $1\left(\delta_{\mathrm{H}}\right.$ 7.66). These data led to the conclusion that leptoclinidamide has the structure 1 as shown in Figure 1.

Table 1. ${ }^{13} \mathrm{C}(100 \mathrm{MHz})$ and ${ }^{1} \mathrm{H}(400 \mathrm{MHz})$ NMR data for leptoclinidamide (1) in DMSO- $d_{6}$.

\begin{tabular}{cccc}
\hline No. & $\boldsymbol{\delta}_{\mathbf{C}}$ & $\boldsymbol{\delta}_{\mathbf{H}}(\boldsymbol{J}$ in $\mathbf{H z})$ & HMBC \\
\hline $1-\mathrm{NH}$ & - & $10.8 \mathrm{brs}$ & $3,4,9$ \\
2 & 122.5 & $7.09 \mathrm{~d}(2.0)$ & $3,4,9$ \\
3 & 111.8 & - & \\
4 & 127.2 & - & 9 \\
5 & 118.1 & $7.48 \mathrm{~d}(8.0)$ & 4 \\
6 & 118.1 & $6.93 \mathrm{t}(8.0)$ & 9 \\
7 & 120.8 & $7.02 \mathrm{t}(8.0)$ & 4 \\
8 & 111.3 & $7.29 \mathrm{~d}(8.0)$ & \\
9 & 136.2 & - & $2,3,4$ \\
10 & 25.1 & $2.77 \mathrm{brt}(7.4)$ &
\end{tabular}


Table 1. Cont.

\begin{tabular}{cccc}
\hline No. & $\boldsymbol{\delta}_{\mathbf{C}}$ & $\boldsymbol{\delta}_{\mathbf{H}}(\boldsymbol{J}$ in Hz) & HMBC \\
\hline 11 & 39.2 & 3.29 brt $(7.4)$ & 3,13 \\
$12-\mathrm{NH}$ & - & 7.93 brt $(5.8)$ & \\
13 & 170.0 & - & \\
14 & 35.2 & 2.24 brt $(7.4)$ & 13 \\
15 & 35.3 & 3.23 brt (7.4) & 13 \\
$16-\mathrm{NH}$ & - & 8.07 brt (5.8) & 17 \\
17 & 169.2 & - & \\
18 & 31.9 & 2.38 brt (7.4) & 17 \\
19 & 35.3 & 2.93 brt (7.4) & 17 \\
$20-\mathrm{NH}_{2}$ & - & 7.66 brs & \\
\hline
\end{tabular}

Figure 2. ${ }^{1} \mathrm{H}-{ }^{1} \mathrm{H}$ COSY and HMBC correlations of leptoclinidamide (1).
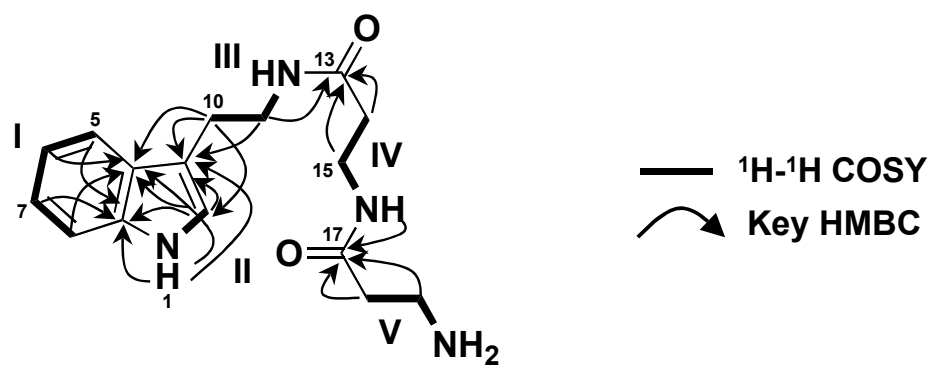

Compound 2 showed a molecular ion peak at $m / z 362[\mathrm{M}+\mathrm{H}]^{+}$in the FAB-MS, and the molecular formula $\mathrm{C}_{16} \mathrm{H}_{20} \mathrm{~N}_{5} \mathrm{O}_{5}$ was deduced from $\mathrm{HRFAB}-\mathrm{MS}$. The NMR spectrum of 2 revealed the presence of a disubstituted indole ring and an arginine moiety. A literature to search suggested the structure of (+)-leptoclinidamine B (5) as a candidate, and this structure was confirmed by comparing ${ }^{1} \mathrm{H}$ and ${ }^{13} \mathrm{C}$ NMR data for $\mathbf{2}$ with those for the reported values [9]. Compound $\mathbf{5}$ was originally isolated from an ascidian Leptoclinides durus and showed no apparent antiprotozoal or cytotoxic activity [9]. Although ${ }^{1} \mathrm{H}$ and ${ }^{13} \mathrm{C}$ NMR spectra of $\mathbf{2}$ were identical to those of $\mathbf{5}$, the sign of the specific rotation of $\mathbf{2}$ was negative $\left([\alpha]_{\mathrm{D}}-20.6\right.$ in $\left.\mathrm{MeOH}\right)$, suggesting that compound $\mathbf{2}$ was the enantiomer of $5\left([\alpha]_{\mathrm{D}}+27.0\right.$ in $\mathrm{MeOH}$ ) [4]. To determine the absolute configulation of 2, amino acid analysis was carried out by the methods described in the Experimental Section. The acid hydrolysate of $\mathbf{2}$ was analyzed by using chiral HPLC. In the analysis, an amino acid in the hydrolysate of $\mathbf{2}$ was detected at 3.7 min, which corresponded to D-Arg (L-Arg eluted at $11.3 \mathrm{~min}$ ). This result was confirmed by Marfey's method [10,11]. The hydrolysate of $\mathbf{2}$ was treated with Marfey's reagent, 5-fluoro-2,4-dinitrophenyl-L-leucine amide (L-FDLA), and the resulting derivative was analyzed by HPLC using an ODS column. An L-FDLA derivative of an amino acid in the hydrolysate of $\mathbf{2}$ showed the same retention time as that of the derivative from D-Arg (13.4 min), whereas the L-FDLA derivative of L-Arg eluted at $15.9 \mathrm{~min}$. Consequently, the absolute stereochemistry of $\mathbf{2}$ was determined to be $13 R$, as shown in Figure 1 . Very recently, herdmanines A-D containing a D-Arg unit were isolated from a solitary ascidian Herdmania momus [12].

No biological activities have been reported for compound 3. Compounds 1-4 were tested for their cytotoxicity against two human cancer cell lines (colon adenocarcinoma HCT-15 and T-cell leukemia 
Jurkat cells). However, none of the four compounds displayed activity against these cell lines at $30 \mu \mathrm{M}$. Since fractions 2, 3, and 6, from which respective compounds 3, 2, and $\mathbf{1}$ were isolated, did not show growth inhibitory activity against four microorganisms (see Experimental Section), compounds 1-3 will not have antimicrobial activity. Further study on biological activity of $\mathbf{1}$ is now in progress. More L. dubius will be collected from the same site to provide sufficient amounts of the antibacterial component for structural characterization.

\section{Experimental Section}

\subsection{General}

FAB-MS spectra were obtained using a JEOL JMS-MS 700 mass spectrometer (Tokyo, Japan). ${ }^{1} \mathrm{H}$ and ${ }^{13} \mathrm{C}$ NMR spectra were recorded on a JEOL JNM-AL-400 NMR spectrometer $\left(400 \mathrm{MHz}\right.$ for ${ }^{1} \mathrm{H}$ and $100 \mathrm{MHz}$ for $\left.{ }^{13} \mathrm{C}\right)$ in DMSO- $d_{6}\left(\delta_{\mathrm{H}} 2.46, \delta_{\mathrm{C}} 39.5\right)$ or $\mathrm{CD}_{3} \mathrm{OD}\left(\delta_{\mathrm{H}} 3.31, \delta_{\mathrm{C}} 49.0\right)$. Optical rotations were measured with a JASCO P-2300 digital polarimeter (Tokyo, Japan). UV spectra were recorded on a Hitachi U-3310 UV-Visible spectrophotometer (Tokyo, Japan) and IR spectra on a PerkinElmer Spectrum One Fourier transform infrared spectrometer (Waltham, MA, USA). Preparative HPLC was carried out with a Hitachi L-6200 system.

\subsection{Materials}

Fetal bovine serum (FBS) and other culture materials were purchased from Invitrogen (Carlsbad, CA, USA). 3-(4,5-Dimethylthiazol-2-yl)-2,5-diphenyltetrazolium bromide (MTT) was purchased from Sigma-Aldrich (St. Louis, MO, USA). All other chemicals and organic solvents were purchased from Wako Pure Chemical Industries Ltd. (Osaka, Japan).

\subsection{Ascidian}

The ascidian was collected by scuba diving at the coral reef in the Lembeh Strait, North Sulawesi, Indonesia in October 2009 and identified as Leptoclinides dubius by T. N. The voucher specimen is deposited at the National Museum of Nature and Science, Tokyo as NSMT Pc-1123.

\subsection{Extraction and Isolation}

The ascidian (250 g, wet weight) was cut into small pieces and soaked in EtOH on a boat immediately after collection. The organism was further extracted twice with EtOH. The EtOH extract ( $3.57 \mathrm{~g}$ ) was suspended in $\mathrm{H}_{2} \mathrm{O}$ and adsorbed on an ODS column (100 g). The ODS column was eluted stepwise with $0,30,50,70$, and $100 \% \mathrm{MeOH}$ in $0.10 \%$ TFA aqueous solution into nine fractions (fraction 1-fraction 9). Fraction 2, eluted with $\mathrm{H}_{2} \mathrm{O}$, was concentrated to yield a red brown oil (108.0 mg), and $20.0 \mathrm{mg}$ of the fraction was purified by preparative HPLC column, PEGASIL ODS $(10 \mathrm{~mm} \times 250 \mathrm{~mm})$; solvent, $35 \% \mathrm{MeOH}$ containing $0.10 \% \mathrm{TFA}$; flow rate, $2.0 \mathrm{~mL} / \mathrm{min}$; detection, UV at $210 \mathrm{~nm}$ ] to give compound 3 (eluted at $9.9 \mathrm{~min}$ ) as a colorless solid (6.0 $\mathrm{mg}$ ). Fraction 3, eluted with $30 \% \mathrm{MeOH}$, was concentrated to yield a red brown oil $(399.5 \mathrm{mg})$, and $20.0 \mathrm{mg}$ was fractionated by preparative HPLC (same conditions as Fraction 2) to yield compound 2 (eluted at $11.0 \mathrm{~min}$ ) as a pale yellow oil $(4.0 \mathrm{mg})$. Fraction $5(95.0 \mathrm{mg})$, eluted with $50 \% \mathrm{MeOH}$, was active against $E$. coli and 
subjected to ODS HPLC with $40 \% \mathrm{MeOH}$ containing $0.10 \%$ TFA (the other conditions were the same as above) into six fractions (Fraction 5-1-Fraction 5-6). Fraction 5-6 showed the growth inhibition against E. coli, but the amounts were not enough to obtain a good ${ }^{1} \mathrm{H}$ NMR spectrum. Fraction 6 , eluted with $50 \% \mathrm{MeOH}$, was concentrated to dryness $(50.5 \mathrm{mg})$, and $20.0 \mathrm{mg}$ was separated by preparative HPLC with the same conditions as Fraction 5 and afforded compound $\mathbf{1}$ (eluted at $15.0 \mathrm{~min})$ as a colorless oil $(2.0 \mathrm{mg})$.

Leptoclinidamide (1): obtained as TFA salt; UV $\lambda_{\max }(\mathrm{MeOH}) \mathrm{nm}(\log \varepsilon): 202$ (4.47), 221 (4.31); IR $v_{\max }(\mathrm{KBr}) \mathrm{cm}^{-1}: 3418,2938,1680,1584,1556,1457$; HRFAB-MS $(\mathrm{m} / \mathrm{z})$ found: 303.1821 , calcd: 303.1821 $[\mathrm{M}+\mathrm{H}]^{+}$for $\mathrm{C}_{16} \mathrm{H}_{23} \mathrm{~N}_{4} \mathrm{O}_{2} ;{ }^{1} \mathrm{H}$ and ${ }^{13} \mathrm{C}$ NMR data, see Table 1 .

(-)-Leptoclinidamine B (2): obtained as TFA salt; $[\alpha]^{20}-20.6(c=0.033, \mathrm{MeOH})$; UV $\lambda_{\max }$ $(\mathrm{MeOH}) \mathrm{nm}(\log \varepsilon): 203$ (4.38), 247 (3.78), 284 (3.78), 334 (3.22); IR $v_{\max }(\mathrm{KBr}) \mathrm{cm}^{-1}$ : 3384, 1684, 1638, 1450, 1275, 1131; HRFAB-MS $(\mathrm{m} / \mathrm{z})$ found: 362.1465 , calcd: $362.1464[\mathrm{M}+\mathrm{H}]^{+}$for $\mathrm{C}_{16} \mathrm{H}_{20} \mathrm{~N}_{5} \mathrm{O}_{5} ;{ }^{1} \mathrm{H}-\mathrm{NMR}$ (DMSO- $\left.d_{6}\right) \delta_{\mathrm{H}} 1.53(2 \mathrm{H}, \mathrm{m}, \mathrm{H}-15), 1.77,1.86$ (2H, m, H-14), 3.14 (2H, m, $\mathrm{H}-16), 4.28\left(1 \mathrm{H}\right.$, brs, H-13), $6.75(1 \mathrm{H}, \mathrm{d}, J=8.0 \mathrm{~Hz}, \mathrm{H}-6), 6.87(1 \mathrm{H}, \mathrm{s}, \mathrm{H}-8), 7.12\left(4 \mathrm{H}, \mathrm{brs}, 18-\mathrm{N}_{2} \mathrm{H}_{4}\right)$, $7.62(1 \mathrm{H}$, brs, $17-\mathrm{NH}), 7.97(1 \mathrm{H}, \mathrm{d}, J=8.0 \mathrm{~Hz}, \mathrm{H}-5), 8.52(1 \mathrm{H}, \mathrm{s}, 12-\mathrm{NH}), 8.72$ (1H, brd, H-2), 9.33 $\left(1 \mathrm{H}\right.$, brs, 7-OH), $11.9\left(1 \mathrm{H}\right.$, brs, 1-NH); ${ }^{13} \mathrm{C}-\mathrm{NMR}$ (DMSO- $\left.d_{6}\right) \delta_{\mathrm{C}} 25.2(\mathrm{C}-15), 27.9(\mathrm{C}-14), 40.3$ (C-16), 51.9 (C-13), 97.2 (C-8), 112.4 (C-6), 112.5 (C-3), 118.8 (C-4), 121.7 (C-5), 137.3 (C-2), 137.5 (C-9), 154.6 (C-7), 156.7 (C-18), 163.5 (C-11), 173.0 (C-20), 181.3 (C-10).

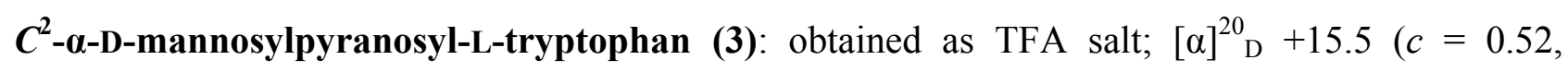
$\mathrm{MeOH})$; FAB-MS $(\mathrm{m} / \mathrm{z}): 367[\mathrm{M}+\mathrm{H}]^{+} ;{ }^{1} \mathrm{H}-\mathrm{NMR}\left(\mathrm{CD}_{3} \mathrm{OD}\right) \delta_{\mathrm{H}} 3.31,3.65(2 \mathrm{H}, \mathrm{m}), 3.65(1 \mathrm{H}, \mathrm{m}), 3.65$, $4.29(2 \mathrm{H}, \mathrm{m}), 3.89(1 \mathrm{H}, \mathrm{m}), 3.97(1 \mathrm{H}, \mathrm{m}), 4.05$ (1H, brd $), 4.25(1 \mathrm{H}$, brdd), $5.04(1 \mathrm{H}, \mathrm{brd}), 7.07$ (1H, t, $J=7.8 \mathrm{~Hz}), 7.11(1 \mathrm{H}, \mathrm{t}, J=7.8 \mathrm{~Hz}), 7.38(1 \mathrm{H}, \mathrm{d}, J=7.8 \mathrm{~Hz}), 7.63(1 \mathrm{H}, \mathrm{d}, J=7.8 \mathrm{~Hz})$.

\subsection{Synthesis of N-Acetyl Derivative (4) of Compound $\mathbf{1}$}

Acetic anhydride $(120 \mu \mathrm{L})$ was added to a solution of fraction $6(20 \mathrm{mg})$ in $\mathrm{MeOH}(340 \mu \mathrm{L})$ at room temperature. The mixture was stirred for $12 \mathrm{~h}$ and evaporated. The residue was purified by preparative HPLC (40\% MeOH containing 0.10\% TFA) using ODS column (PEGASIL ODS) to give $1.0 \mathrm{mg}$ of 4: HRFAB-MS $(m / z)$ found: 345.1930 , calcd: $345.1927[\mathrm{M}+\mathrm{H}]^{+}$for $\mathrm{C}_{18} \mathrm{H}_{25} \mathrm{~N}_{4} \mathrm{O}_{3} ;{ }^{1} \mathrm{H}-\mathrm{NMR}$ (DMSO- $d_{6}$ ) $\delta_{\mathrm{H}} 1.75(3 \mathrm{H}, \mathrm{s}), 2.17(2 \mathrm{H}, \mathrm{t}, J=7.6 \mathrm{~Hz}), 2.21(2 \mathrm{H}, \mathrm{t}, J=7.6 \mathrm{~Hz}), 2.79(2 \mathrm{H}, \mathrm{t}, J=7.6 \mathrm{~Hz}), 3.18(2 \mathrm{H}, \mathrm{t}$, $J=7.6 \mathrm{~Hz}), 3.22(2 \mathrm{H}, \mathrm{t}, J=7.6 \mathrm{~Hz}), 3.31(2 \mathrm{H}, \mathrm{t}, J=7.6 \mathrm{~Hz}), 6.95(1 \mathrm{H}, \mathrm{t}, J=7.4 \mathrm{~Hz}), 7.04(1 \mathrm{H}, \mathrm{t}$, $J=7.4 \mathrm{~Hz}), 7.11(1 \mathrm{H}, \mathrm{d}, J=8.3 \mathrm{~Hz}), 7.31(1 \mathrm{H}, \mathrm{d}, J=8.3 \mathrm{~Hz}), 7.50(1 \mathrm{H}, \mathrm{d}, J=2.0 \mathrm{~Hz}), 7.78(\mathrm{NH}, 1 \mathrm{H}$, brt, $J=5.4 \mathrm{~Hz}), 7.85(\mathrm{NH}, 1 \mathrm{H}$, brt, $J=5.8 \mathrm{~Hz}), 7.93(\mathrm{NH}, 1 \mathrm{H}$, brt, $J=5.8 \mathrm{~Hz}), 10.8(\mathrm{NH}, 1 \mathrm{H}$, brs $)$.

\subsection{Acid Hydrolysis of Compound 2}

Compound $2(0.5 \mathrm{mg})$ was suspended in $6.0 \mathrm{~N} \mathrm{HCl}(1.0 \mathrm{~mL})$ and heated at $100{ }^{\circ} \mathrm{C}$ for $8 \mathrm{~h}$. The mixture was cooled to room temperature and evaporated to dryness. 


\subsection{Chiral HPLC of Peptide Hydrolysate}

Hydrolysate of 2 was dissolved in $\mathrm{H}_{2} \mathrm{O}(0.4 \mathrm{~mL})$ and $5.0 \mu \mathrm{L}$ was analyzed by HPLC using the following condition (A): L-6200 system; column, SUMICHIRAL OA-6000 (Sumika Chemical Analysis Service, Ltd., Tokyo, Japan), $4.6 \times 150 \mathrm{~mm}$; flow rate, $1.0 \mathrm{~mL} / \mathrm{min}$; detection, UV $254 \mathrm{~nm}$; mobile phase, $2 \mathrm{mM} \mathrm{CuSO}_{4}$ in $2.0 \% \mathrm{CH}_{3} \mathrm{CN}$. Authentic L- and D-Arg were eluted at 11.3 and $3.7 \mathrm{~min}$, respectively. An amino acid in the hydrolysate of 2 was detected at $3.7 \mathrm{~min}$.

\subsection{Marfey's Analysis}

Hydrolysate of 2 was dissolved in $1 \mathrm{M} \mathrm{NaHCO}_{3}(200 \mu \mathrm{L})$ and reacted with $1 \% \mathrm{~L}-\mathrm{FDLA}(100 \mu \mathrm{L}$ in acetone) at $40{ }^{\circ} \mathrm{C}$ for $2 \mathrm{~h}$. After cooling, the sample was quenched with $1 \mathrm{~N} \mathrm{HCl}$ and dried under vacuum. The solid residue was dissolved in $50 \%$ aq $\mathrm{CH}_{3} \mathrm{CN}(400 \mu \mathrm{L})$ and analyzed under the following condition (B): L-6200 system; column, Pegasil ODS SP100 (Senshu Scientific), $4.6 \times 250$ mm; flow rate, $0.8 \mathrm{~mL} / \mathrm{min}$; detection, UV $340 \mathrm{~nm}$; mobile phase, a liner gradient from $30 \%$ to $60 \%$ $\mathrm{CH}_{3} \mathrm{CN}$ containing $0.05 \%$ TFA. L-FDLA derivatives of authentic L- and D-Arg eluted at 15.9 and $13.4 \mathrm{~min}$, respectively, and the L-FDLA derivative in the hydrolysate of $\mathbf{2}$ was detected at $13.4 \mathrm{~min}$.

\subsection{Antimicrobial Assay}

The growth inhibitory activity was examined by the paper disk method against Mucor hiemalis IAM 6088 (fungus), Saccharomyces cerevisiae IAM 1438T (yeast), Staphylococcus aureus IAM 12544T (Gram-positive bacterium), and Escherichia coli IAM 12119T (Gram-negative bacterium) as test microorganisms. A paper disk containing $250 \mu \mathrm{g}$ of the test sample was placed on a test plate.

\subsection{Cytotoxicity Assay}

HCT-15 and Jurkat cells were obtained from the Center for Biomedical Research, Institute of Development, Aging, and Cancer, Tohoku University (Miyagi, Japan). Two cell lines were cultured in RPMI-1640 medium. The medium was supplemented with $10 \%$ fetal bovine serum, 100 units $/ \mathrm{mL}$ penicillin, and $100 \mu \mathrm{g} / \mathrm{mL}$ streptomycin. Exponentially growing cells cultured in a humidified chamber at $37{ }^{\circ} \mathrm{C}$ containing $5.0 \% \mathrm{CO}_{2}$ were used for the experiments.

Cytotoxic activity was evaluated using the colorimetric MTT assay [13]. HCT-15 cells $\left(1.0 \times 10^{4}\right.$ cells in $\left.100 \mu \mathrm{L}\right)$ or Jurkat cells $\left(2.0 \times 10^{4}\right.$ cells in $\left.100 \mu \mathrm{L}\right)$ were added to each well of a 96-well plastic plate (Corning Inc., Corning, NY, USA). A sample (1.0 $\mu \mathrm{L}$ in $\mathrm{MeOH}$ ) was added to each well to make the final concentration from 0 to $27 \mu \mathrm{M}$ and the cells were incubated for 48 hours at $37{ }^{\circ} \mathrm{C}$. MTT $(10 \mu \mathrm{L}$ of $5.5 \mathrm{mg} / \mathrm{mL}$ stock solution) and a cell lysate solution $(90 \mu \mathrm{L}, 40 \%$ $\mathrm{N}, \mathrm{N}$-dimethylformamide, $20 \%$ sodium dodecyl sulfate, $2.0 \% \mathrm{CH}_{3} \mathrm{COOH}$ and $0.030 \% \mathrm{HCl}$ ) were added to each well, and the plate was shaken thoroughly by agitation at room temperature for overnight. The optical density of each well was measured at $570 \mathrm{~nm}$ using an MTP-500 microplate reader (Corona Electric Co., LTD., Ibaraki, Japan). 


\section{Conclusions}

Two new tryptamine derivatives, leptoclinidamide (1) and (-)-leptoclinidamine B (2), were isolated from the EtOH extract of an Indonesian ascidian Leptoclinides dubius together with a known compound, $C^{2}$ - $\alpha$-D-mannosylpyranosyl-L-tryptophan (3). Biological activity of compound $\mathbf{3}$ has not been clarified, and, in this study, we found that compounds 1-4 were not active against two human cancer cell lines (HCT-15 and Jurkat) and four microorganisms (Gram positive and negative bacteria, yeast, and fungus). An antibacterial component against $E$. coli was also obtained from the EtOH extract, but the structure has not been determined because the amounts were not enough to measure 2D NMR spectra.

\section{Acknowledgments}

This work was supported in part by a Grant-in-aid for Scientific Research (21603012) from the Ministry of Education, Culture, Sports, Science, and Technology (MEXT) of Japan to MN and by a Colab. Res. \& Int. Pub. Project No. 492/SP 2H/PL/2011 from DGHE, Ministry of National Education of Indonesia to REPM. We are grateful to the Center for Biomedical Research, Institute of Development, Aging and Cancer, Tohoku University for kindly providing human cancer cell lines.

\section{References}

1. Faulkner, D.J. Marine natural products. Nat. Prod. Rep. 2002, 19, 1-48, and previous reports in this series.

2. Blunt, J.W.; Copp, B.R.; Munro, M.H.G.; Northcote, P.T.; Prinsep, M.R. Marine natural products. Nat. Prod. Rep. 2011, 28, 196-268, and previous reports in this series.

3. Wang, W.F.; Namikoshi, M. Bioactive nitrogenous metabolites from ascidians. Heterocycles 2007, 74, 53-88.

4. De Beer, T.; Vliegenthart, J.F.G.; Loffler, A.; Hofsteenge, J. The hexopyranosyl residue that is $C$-glycosidically linked to the side chain of tryptophan-7 in human RNase Us is a-mannopyranose. Biochemistry 1995, 34, 11785-11789.

5. Gutsche, B.; Grun, C.; Scheutzow, D.; Herderich, M. Tryptophan glycoconjugates in food and human urine. Biochem. J. 1999, 343, 11-19.

6. Manabe, S.; Ito, Y. Total synthesis of novel subclass of glyco-amino acid structure motif: $C^{2}$ - $\alpha$-L-C-mannosylpyranosyl-L-tryptophan. J. Am. Chem. Soc. 1999, 121, 9754-9755.

7. Nishikawa, T.; Ishikawa, M.; Isobe, M. Synthesis of a $\alpha$ - $C$-mannosyltryptophan derivative, naturally occurring $C$-glycosyl amino acid found in human ribonuclease. Synlett 1999, 123-125.

8. Garcia, A.; Lenis, L.A.; Jimenez, C.; Debitus, C.; Quinoa, E.; Riguera, R. The occurrence of the human glycoconjugate $C^{2}$ - $\alpha$-D-mannosylpyranosyl-L-tryptophan in marine ascidians. Org. Lett. 2000, 2, 2765-2767.

9. Carroll, A.R.; Avery, V.M. Leptoclinidamines A-C, indole alkaloids from the Australian ascidian Leptoclinides durus. J. Nat. Prod. 2009, 72, 696-699.

10. Marfey, P. Determination of D-amino acids. II. Use of a bifunctional reagent, 1,5-difluoro-2,4dinitrobenzene. Carlsberg Res. Commun. 1984, 49, 591-596. 
11. Kuo, H.K.; Kai, K.; Akiyama, K.; Hayashi, H. Novel bioactive peptides, PF1171F and PF1171G, from unidentified ascomycete OK-128. Tetrahedron Lett. 2012, 53, 429-431.

12. Li, J.L.; Han, S.C.; Yoo, E.S.; Shin, S.; Hong, J.; Cui, Z.; Li, H.; Jung, J.H. Anti-inflammatory amino acid derivatives from the ascidian Herdmania momus. J. Nat. Prod. 2011, 74, 1792-1797.

13. Mosmann, T. Rapid colorimetric assay for cellular growth and survival: application to proliferation and cytotoxicity assays. J. Immunol. Methods 1983, 65, 55-63.

Samples Availability: Not available.

(C) 2012 by the authors; licensee MDPI, Basel, Switzerland. This article is an open access article distributed under the terms and conditions of the Creative Commons Attribution license (http://creativecommons.org/licenses/by/3.0/). 